\title{
Ant Colony Optimization による最適経路探索アルゴリズムの構築と
}

\section{道路線形最適化問題への応用に関する研究}

Study on Algorithm for Searching the Optimum Path by Ant Colony Optimization and its Application to Optimum Road Alignment

\author{
阿部淳一*・杉本博之** \\ Junichi ABE and Hiroyuki SUGIMOTO
}

*工博 北武コンサルタント株式会社（广062-0020 札幌市豊平区月寒中央通 7 丁目 4 番 7 号）

** 工博 北海学園大学教授 社会環境工学科（T064-0926 札幌市中央区南26 条西 11 丁目）

\begin{abstract}
Ant Colony Optimization (abbreviated as ACO after) is an optimization method based on the efficient foraging behavior of ant colonies. The ACO can be regarded as the specialized method for searching the shortest paths. So the method has been applied restrictively to only the impractical problem that has a concept of paths like traveling salesman problem. For such a problem like a TSP, it was concluded that the ACO showed the superiority to Genetic Algorithms in efficiency and accuracy. From such a point of view, in this paper, by studying the efficient behavior of ant colonies the searching method applicable to the road or railway planning or channel planning is proposed. The proposed method is applied to find the optimum three-dimensional road alignment and shows the practicability and validity.
\end{abstract}

Key Words: ACO, optimum design, 3-D road alignment, road design

\section{1. まえがき}

群れを成して行動する昆虫や動物などは，単体では単 純な原理に従い行動しているが，集団になると時として 効率的な行動をとることがある.このような効率的な群 行動は Swarm Intelligence として数值モデル化され, 種々 の分野で研究が行われている. その中でむ，蟻の採领行 動は身近に確認できる代表的な群行動の1つである.

蟻の集団が餌を探して巣に持ち帰るとき，始めは巣と 餌場までの間をランダムに行動している. しかし，ある 蟻が巣と餌場までの短い経路を探索すると，他の蟻はそ の経路に寄ってくる. 寸ると, やがて蟻の集団は巣と餌 場までの最短経路を探し出し, その最短経路に列を成し て行動する. このとき, 各蟻は情報交換の手段として, フェロモンを使用するとされている．蟻はより短い経路 に多くのフェロモンを分泌し，またより多くのフェロモ ンがある箇所に集まる習性を持つ. 各蟻がフェロモンを 使用することにより，群全体で最短の経路を探索する. このような, 蟻の効率的な経路選択の群行動をモデル化 し, 最適化手法に取り入れた Ant Colony Optimization(以 下，ACO）と呼ばれる手法がある.

ACO は Dorigo')らによって提案された手法で, 組み合 わせ最適化問題の中でも爆発的な設計空間となる巡回セ ールスマン問題 (Traveling Salesman Problem, 以下, TS P）を解くために提案された. ACOは前述のように，蟻
が最短の経路を探索することをモデル化しているため, 経路の概念を有寸る設計問題に対して効率的に解の探索 を行えることが特徴である. 筆者らもこれまでに, ACO をTSP に応用していくつかの数値計算を試みたが, 他の 最適化手法と比較しても非常に高い効果が確認された ${ }^{2)}$. しかし，現実の設計問題のなかで，最短の経路を探索す るような問題け比較的少なく, $\Lambda C O$ を現実的な設計問題 へ応用した事例もやはり少ないと考えられる。

一方, $\mathrm{ACO}$ の基となる蟻の効率的な採餌行動とは, 最 短経路を探索する行為であり，これはすなわち，道を形 成する行為である. この道を形成する行為を人間社会に 例えると, 土木分野における道路や鉄道の路線計画や, 河道計画に他ならない：これらの計画では，景観性への 配慮や様々な制約条件など多くの検討事項を含むが，基 本的には工費最小化を目的として行われる. 工費にも 種々の項目が含まれるが，基本的にはより短い線形であ るほど工費は减少する，そのため，短い経路を探索する 能力に特化した ACO の論理を, 上述の路線や河道の設 計問題に拡張を行えば，効率的な経路の最適化が可能に なると考えられる.

一方, 路線の設計問題に対して最適化を試みた事例に, 山崎らの研究がある ${ }^{4)}$. 山崎らは高速道路を対象として, 最適化に適した路線の線形モデルを構築し, 遺伝的アル ゴリズム ${ }^{3)}$ (以下，GA）を用いた最適化を行っている. しかし，3 次元空間を設計空間とした場合，検討可能な 
路線の組み合わせ数は爆発的となることは自明である. このように爆発的な路線の組み合わせの中から，最適な 経路を探索する路線設計問題は, 前述の TSP と同質の設 計問題であると考えられる，そのため，筆者らの過去の 研究からも, 路線設計問題の最適化に対しては, ACO を 用いることの有効性が期待できる.

このような観点から，本論文では蟻の効率的な群行動 である道を形成する行為に着目し，ACO を基とした 3 次元空間内に対して最適経路を探索するアルゴリズムの 構築を試みるものである. また，このアルゴリズムは, 3 次元空間内に対して経路を作成する道路や鉄道の路線計 画，あるいは河道計画などの様々な問題に適用可能であ り，本論文では道路の路線設計最適化問題へ応用を試み た事例について示す.

\section{ACO の概要}

ここでは, ACOの概要について説明する. 蟻の採䬣行 動をモデルとした ACO は, 蟻の経路選択行動とフェロ モンを数值モデル化することにより最適化を行う. 図一 1 にACO のアルゴリズムを示す，図のように ACO は5 つの STEP で構成され，比較的簡単なアルゴリズムとな る. 以下に, アルゴリズムの各 STEP について説明する.

なお，ここでは ACO の概要を把握することを目的と して，まずTSP を解くために提案された ACO について 説明する，後に，本論文が ACO を基に改良を行ったア ルゴリズムについて説明する.

\section{STEP1：初期化}

初期化を行う. 各蟻の初期位置をランダムに設定し， 全経路のフェロモン情報を一定量に初期化する.

\section{STEP2 : 巡回路の構築}

訪問する都市を順次選択し，巡回路の構築を行う。訪 問する都市は，フェロモン情報，およびヒューリスティ ック情報と呼ばれる二つの情報から, 各蟻が確率的に選 択する. フェロモン情報，およびヒューリスティック情 報についての詳細は後述する.

蟻の総数を $N_{A}$ とすると, $n\left(n=1 \sim N_{A}\right)$ 番目の蟻が都 市 $i$ から $j$ に行く経路 $(i-j)$ を選択する確率 $P_{i j n}(t)$ は, 次式で表される.

$$
\left.\begin{array}{l}
P_{i j n}(t)=\frac{\tau_{i j}(t)^{\alpha} \cdot \eta_{i j}{ }^{\beta}}{\sum_{j \in C} \tau_{i j}(t)^{\alpha} \cdot \eta_{i j}{ }^{\beta}}\left(i=1 \sim N_{C}, j \in C, n=1 \sim N_{A}\right) \\
P_{i j n}(t)=0 \quad\left(i=1 \sim N_{C}, j \notin C, n=1 \sim N_{A}\right) \\
こ こ て ゙, \\
\tau_{i j}: \text { フェロモン情報 } \\
\eta_{i j}: \text { ヒューリスティック情報 } \\
\alpha: \text { フェロモン情報に対する乗数 }
\end{array}\right\}(1)
$$

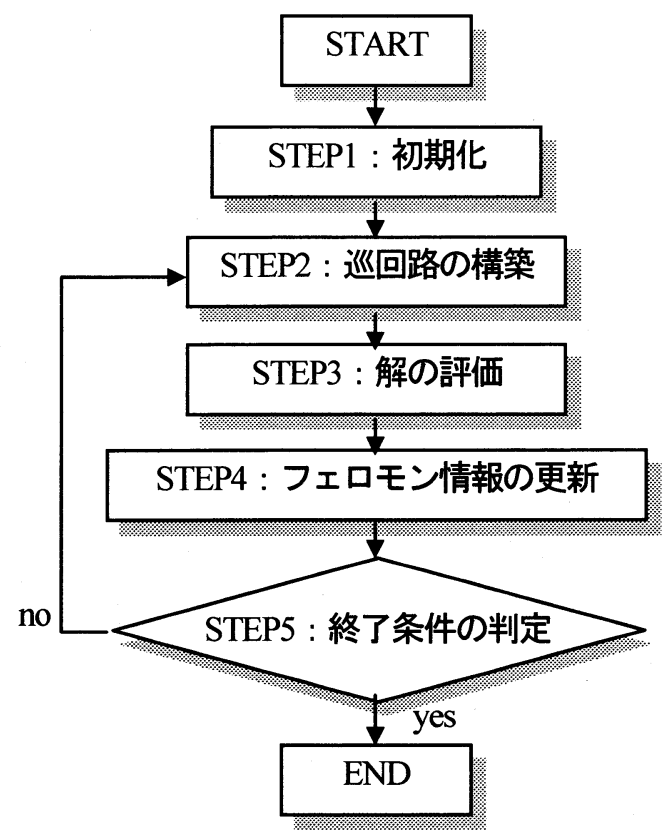

図-1 ACO のアルゴリズム

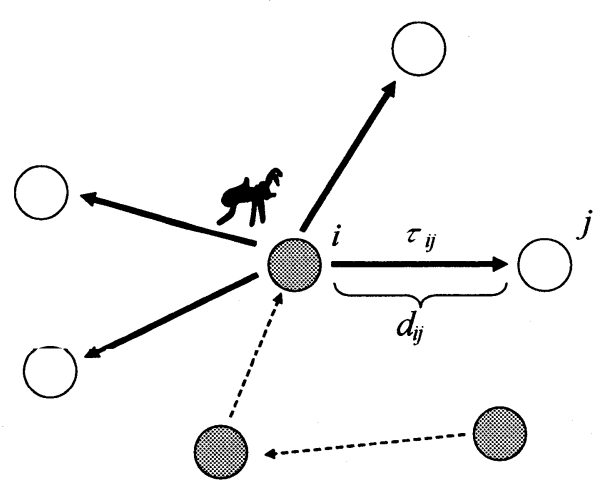

図-2 経路選択の概念図

$\beta:$ ヒューリスティック情報に対する乗数

$C$ : 都市 $i$ から選択することが可能な都市の集合 $N_{c}$ : 都市数

である. 擬似乱数を用いて式(1)により訪問する都市を 順次決定し，巡回路を構築していく.

式(1)のフェロモン情報 $\tau_{i j}$ は，各蟻がこれまで（後述 の STEP4）に経路に付着させてきた情報で，より短い巡 回路ほど高い值となるように付着する.

一方, ヒューリスティック情報 $\eta_{i j}$ は, 経路の距離の逆 数を用いる. $\eta_{i j}$ は, 次式で与えられる.

$$
\begin{aligned}
& \quad \eta_{i j}=\frac{1}{d_{i j}} \quad\left(i=1 \sim N_{C}, j=1 \sim N_{C}\right) \\
& \text { ここで, } \\
& \quad d_{i j}: \text { 経路 }(i-j) \text { の距離 } \\
& \text { である. } \\
& \quad \text { ヒューリスティック情報 } \eta_{i j} \text { は, 蟻が都市を選択する時, }
\end{aligned}
$$


巡回路の総距離に関係無く, より短い経路となる都市ほ ぞ高い確率で選択するような情報となる.

ACO における確率的経路の選択方法の概念図を図一2 に示す．図中の・がこれまで訪問した都市，○が未訪問 都市である. 蟻の現在位置を都市 $i$ として, 未訪問都市 の集合 $C$ の中から都市 $j$ に行く確率は, 経路に蓄積され ているフェロモン情報 $\tau_{i j}$ がより高いほど, また都市まで の距離 $d_{i j}$ がより短いほど高くなるようにモデル化され ている.

\section{STEP3 : 解の評価}

STEP2 において, 各蟻が順次選択した都市の巡回路の 総距離を算定する.

\section{STEP4： フェロモン情報の更新}

ここでは, 巡回路の各経路にフェロモン情報を追加寸 る. TSP の場合, 巡回路の総距離の最小化問題であるた め, 追加されるフェロモン情報は巡回路の総距離が短い ほど高い值とする. よって, 追加されるフェロモン情報 は, 次式で与えられる.

$$
\Delta \tau_{i j n}=\frac{1}{L_{n}}\left(i=1 \sim N_{C}, j=1 \sim N_{C}, n=1 \sim N_{A}\right)
$$

ここで,

$\Delta \tau_{i j n}: n$ 番目の蟻により追加されるフェロモン情報

$L_{n}: n$ 番目の蟻によって選択された巡回路の総距離

である.

経路に蓄積されるフェロモン情報は, 各蟻が選択した 巡回路に対して,式(3)で算定される值を新たに追加する. また，全経路に付着されているフェロモンは, 自然現象 と同様に蒸発することも数值モデル化される.すなわち, ある時間 (繰り返し回数) $t$ におけるフェロモン情報 $\tau_{i j}(t)$ は, $t+1$ において次式で更新される.

$$
\begin{aligned}
& \tau_{i j}(t+1)=(1-\rho) \cdot \tau_{i j}(t)+\sum_{n=1}^{N A} \Delta \tau_{i j n} \\
& \left(i=1 \sim N_{C}, j=1 \sim N_{C}\right) \\
& \text { ここで, } \\
& \rho: \text { フェロモンの蒸発率 }
\end{aligned}
$$

である.

フェロモン情報が時系列的に蒸発することにより, 最 近の行動を重視し局所解に陥ることを回避し, 大域的な 解の探索を可能にする.

\section{STEP5：終了条件の判定}

探索回数が最大回数以下なら STEP2 に戻る. 最大回数 を満足していれば, 終了となる.

$\mathrm{ACO}$ は以上のように, 比較的簡単なアルゴリズムで構 成される. しかし, フェロモン情報とヒューリスティッ ク情報の 2 つ情報を用いることにより, 過去の設計解 （巡回路）に対しての評価のみならず, 個々の設計変数

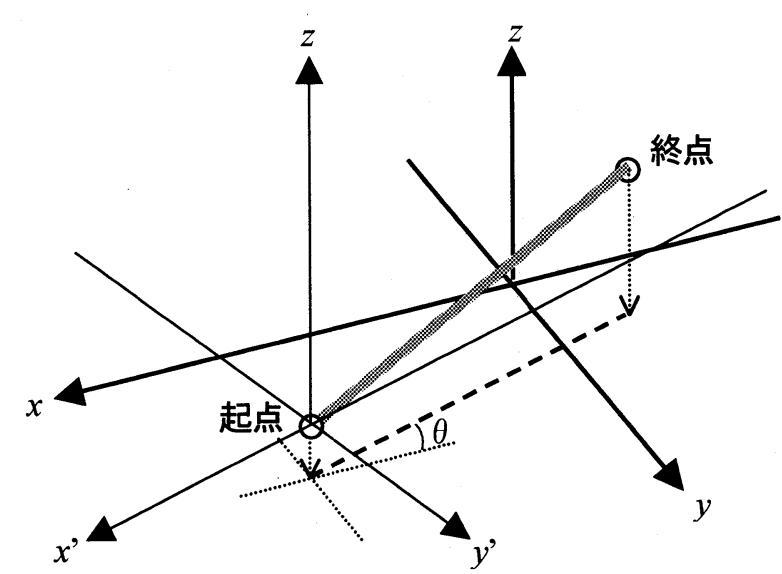

図－3起終点を結ぶ座標系の作成

(経路)に対する評価も設計解の算定に考慮されるため, 最短巡回路の探索に特化した手法となる.

次節では, 上述した $\mathrm{ACO}$ の基本的なアルゴリズムを応 用し, 本研究が提案する最適経路算定アルゴリズムにつ いて示寸.

\section{3. 最適経路算定アルゴリズムの提案}

ここでは，上述の ACO を応用して，本論文が提案す る最適経路算定アルゴリズムについて説明する.

\section{1 設計空間の設定}

最適経路算定アルゴリズムは，3 次元空間内に複数の 蟻を歩かせ, 群全体で最適な経路の算定を行うものとす る.このとき, 蟻の選択寸る経路は, ACO の基本的な論 理である式(1)を用いることを前提とする. 寸なわち, よ り高いフェロモン情報と，ヒューリスティック情報があ る経路ほど，高い確率で選択するようなモデルである. しかし，TSP を解くような一般的な ACO では，与えら れた都市の中から 1 つの都市を順次選択すればよいが， 最適経路探索アルゴリズムでは，3 次元空間の中から進 行する場所を逐次選択しなければならない.

このように, 3 次元空間内に対して式(1)を応用して, 蟻の進行する場所を逐次選択するには，まず 3 次元空間 を離散変数で表す必要がある. そのために，まず本研究 では図ー3のように, $x-y-z$ 平面で表される 3 次元空間内 に, 経路を計画する起点と終点 (図中の○) を設定する. このとき, 起点と終点の $x y$ 座標を抽出し, $x-y$ 平面上で 起点と終点を結ぶ直線（図中の破線）を作成する． $x-y$ 平面上におけるこの直線の傾きを $\theta$ とし， $\theta$ 傾いた座標 系 $x^{\prime}-y^{\prime}-z$ を作成する.

さらに起点から終点内の空間を, 図一4 のように網目 状に分割する. このとき, $x^{\prime}$ 方向の分割数を $N_{x^{\prime}}, y^{\prime}$ 方向 の分割数を $N_{y}, z$ 方向の分割数を $N_{z}$ とする. そして, 
$N_{x}$ 分割された $x$ 方向の分割をさらに $N_{d}$ 分割する.この ように $N_{d} \times N_{y} \times N_{z}$ の網目状に分割された 3 次元空間の 中から 1 点を, 蟻は図一5 のように選択する. 設定した 起点から, 上述の作業を $N_{x}$ 数繰り返して経路を構筑し, $N_{x}$ 数目に選択したメッシュの交点から終点に到着させ ることにより，図一6 のように 3 次元空間内に経路が作 成されることになる.

以上の方法を用いると, 蟻の確率的な経路の選択であ る式(1)は, 3 次元空間における最適経路算定アルゴリズ ムでは次式のようになる.

$$
\left.\begin{array}{rl}
P_{i j n}(t) & =\frac{\tau_{i j}(t)^{\alpha} \cdot \eta_{i j}{ }^{\beta}}{\sum_{j \in c_{i+1}} \tau_{i j}(t)^{\alpha} \cdot \eta_{i j}{ }^{\beta}} \\
(i=1 & \left.\sim N_{x^{\prime}}, j \in c_{i+1}, n=1 \sim N_{A}\right) \\
P_{i j n}(t) & =0 \quad\left(i=1 \sim N_{x^{\prime}}, j \notin c_{i+1}, n=1 \sim N_{A}\right)
\end{array}\right\}
$$

ここで

$\tau_{i j}:$ フェロモン情報

$\eta_{i j}:$ ヒューリスティック情報

$\alpha:$ フェロモン情報に対する乗数

$\beta:$ ヒューリスティック情報に対する乗数

$c_{i+1}: i$ 番目に選択されたメッシュの交点から選択する ことが可能な, $i+1$ 番目の $N_{d} \times N_{y} \times N_{z}$ 数に分割された メッシュ空間の交点の集合

$N_{x^{\prime}}: x^{\prime}$ 方向の分割数

である.

なお， $x$ 方向に対しては， $N_{x}$ 個に分割した後，さらに $N_{d}$ 個に分割している. これは, 道路の設計問題などでは 短区間に曲線を複数個配置はしないが，曲線を配置する 位置は詳細に検討寸る必要性があるためである. $x$ ’方向 を2段階に分割することにより，最大でも $N_{x}$ 個の箇所で 経路の方向が変わり(曲線の配置), その配置位置はそれ ぞれ $x$ 方向に $N_{d}$ 個の候補があることを示している. 当 然 $N_{x^{\prime}}$ の数を増やし， $N_{d}$ を 1 とすれば, $x$ 方向に対して すべてのメッシュで方向が変わる経路を配置可能な設 計問題になる.

一方，提案する手法は， $N_{x}$ 番目に選択したメッシュの 交点から終点へは, 強制的に経路が構築される. そのた め, 解の探索初期の段階では, 最適解とはならないこと が明白な，終点から極端に離れるような経路も選択され， 非効率的な計算が行われていることがいくつか確認さ れた. これは, 起点からのみ蟻を移動させていることが 大きな要因であると考えられ, 今後, 起終点間を往復さ せる論理などの追加の必要性が考えられる.

以上の設計空間の設定により，蟻を 3 次元空間内に歩 かせることが可能となった. この3 次元空間内に, フェ ロモン情報とヒューリスティック情報を設定し, 蟻を確 率的に移動させる. 次節では, 最適経路算定アルゴリズ ムにおける，フェロモン情報とヒューリスティック情報 について説明する.
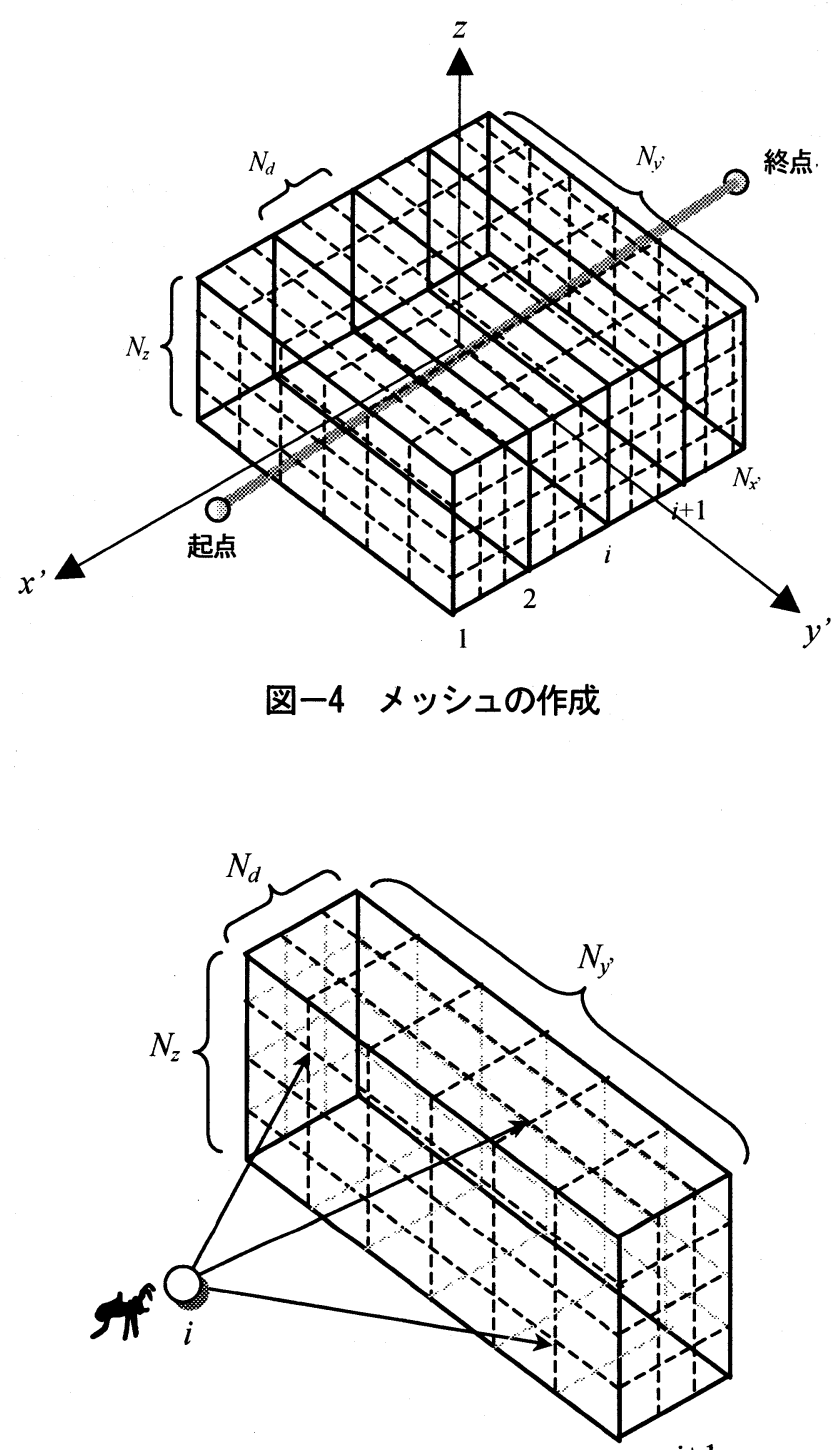

図-5 3 次元空間内の経路選択の概念図

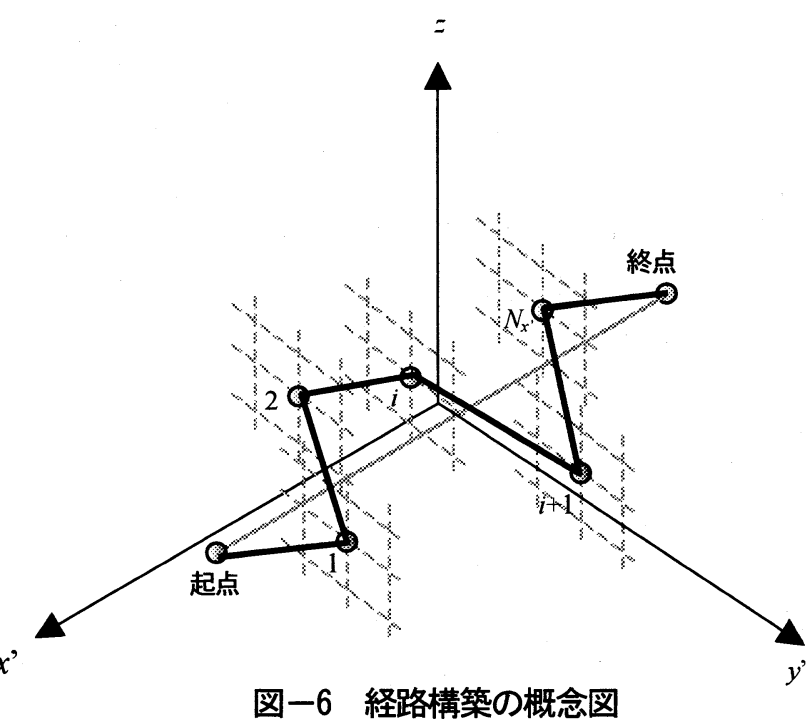




\section{2 フェロモン情報とヒューリスティック情報}

$\mathrm{ACO}$ における確率的な経路の選択は, ヒューリスティ ック情報とフェロモン情報の 2 つ情報を用いる．ヒュ 一リスティック情報は，2.に示した TSP では蟻がより短 い経路であるほど高い確率で選択するとした情報であっ た. 本論文が提案する最適経路算定アルゴリズムでも, 基本的により短い経路を探索する問題を対象とするため, ヒューリスティック情報は,式(2) と同様により短い路線 を高い確率で選択するように，次式により算定される.

$$
\eta_{i j}=\frac{1}{d_{i j} \cdot \gamma_{i j}} \quad\left(i=1 \sim N_{x^{\prime}}, j \in c_{i+1}\right)
$$

ここで,

$\eta_{i j}: i$ 番目に選択されたメッシュの交点から, $i+1$ 番目 に選択したメッシュの交点 $j$ を結んだ経路 $(i-j)$ のヒ ユーリスティック情報

$d_{i j}: i$ 番目と $i+1$ 番目に選択したメッシュの交点を結ん だ経路 $(i-j)$ の距離

$\gamma_{i j}: i$ 番目と $i+1$ 番目に選択したメッシュの交点を結

んだ経路 $(i-j)$ の付加情報

である.

ヒューリスティック情報はメッシュ間の距離の逆数を 用いることにより，TSP の場合と同様な性質を持つ。す なわち，より近い場所に移動を試みようとする情報であ る. これらのように, 距離の概念を直接解の探索に応用 できるため, より短い路線を選択するような問題に対し ては，他の最適化手法と比べ本手法の適用性が高いと考 えられる.

また, 式(6)では式(2)に変わり, 新たに $\gamma_{i j}$ を追加して いる. これは, 経路の距離に関する情報以外に, 対象と する設計問題に固有な情報を付加できるようにしたもの である. たとえば，道路線形最適化問題において，工費 の最小化を試みる場合，より短い経路を算定することの ほかに，切土や盛土などの土工を少なくすることも重要 となる. このとき, $\gamma_{i j}$ には路線の計画高と地盤高の差を 代入すれば，より短い経路であるほど，またより地盤高 に近い経路であるほど高い確率で巽択する上うな情報と なる. このように, $\gamma_{i j}$ を追加することにより, 対象とす る設計問題に応じた様々なヒューリスティック情報を設 定できるものとした.

一方，2.に示した TSP におけるフェロモン情報は， 巡回路長が短いものほど高い值となるように設定された. これは, TSPの目的関数が, 巡回路長の最小化としてい るためである. そこで, 本研究が提案する最適経路算定 アルゴリズムでは，対象とする設計問題に応じた目的関 数が最小化問題であることを前提とし, 目的関数がより 小さいほど高いフェロモン情報となるように設定する. すなわち, 式(3)のフェロモン情報は次式に変換される.

$$
\Delta \tau_{i j n}(t)=\frac{1}{F_{P_{n}}}\left(i=1 \sim N_{x^{\prime}}, j \in c_{i}, n=1 \sim N_{A}\right)
$$

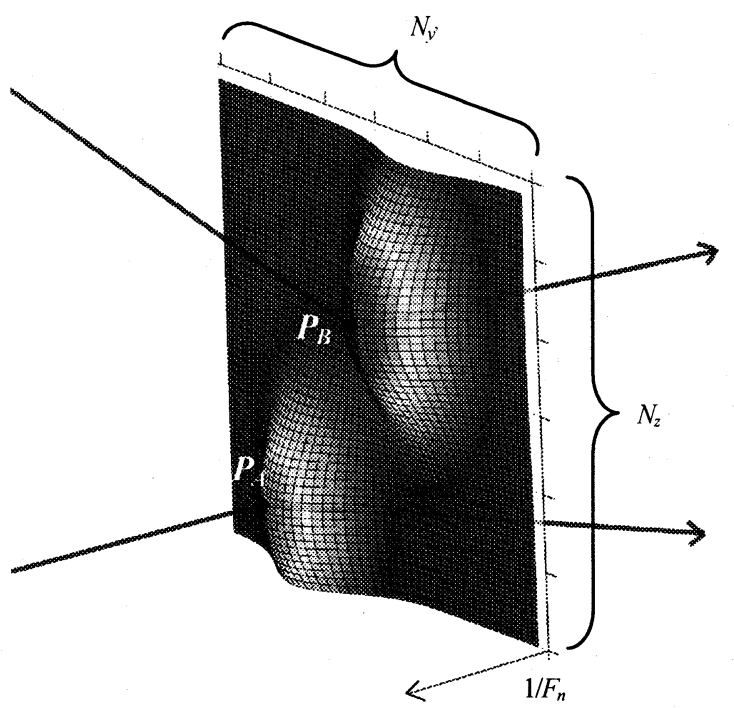

図ー7 フェロモン情報の範囲付着

$\Delta \tau_{\text {ijn }}(t):$ 繰り返し回数 $t$ において, $n$ 番目の蟻が $i$ 番 目に選択したメッシュの交点 $j$ に付与寸るフェロモン 情報

$F_{P n}: F$ (対象とする最適設計問題の目的関数) と $g_{J}$ (対 象とする設計問題の制約条件, $\left.J=1 \sim N_{c}\right)$ 功算定され るペナルティー関数により無制約化した， $n$ 番目の蟻 による設計解の目的関数值

$N_{c}$ : 制約条件の数

である. 式 (7) のように, 設計問題が制約条件付き問題 であることを前提とし，ペナルティー関数を用いて無制 約化した目的関数值をフェロモン情報に用いている.

また, 前述までのように ACOによる最適化は, フェ ロモン情報とヒューリスティック情報を用いるが,式(5) に示寸ように，フェロモン情報の值が 0 であると，その 経路を選択する確率は 0 となってしまう。（ヒューリス ティック情報は距離の情報であるため, 0 にはならない) 大域的な解の算定のためには，より広範囲に探索範囲を 広げる必要があり，そのためには各蟻が設計空問全域に 対してフェロモン情報を付与させる必要がある. しかし， 爆発的な組合せ数の設計空間を有する 3 次元の最適経路 算定問題の場合，設計空間全域に対してフェロモン情報 を付与させることは難しいと考えられる.

そこで本研究では, 従来の ACO のように蟻が通過し た経路のみにフェロモン情報を付与するのではなく，通 過した経路周辺に対して広範囲にフェロモン情報を付与 できるように，式(7)を次式に改良した。

$$
\begin{array}{r}
\Delta \tau_{i j}(t)=\sum_{n=1}^{N_{A}}\left(\frac{1}{F_{P_{n}}} \cdot \exp \left(-\left(\frac{d_{n i x^{\prime}}{ }^{2}}{r_{x^{\prime}}{ }^{2}}+\frac{d_{n i y^{\prime}}{ }^{2}}{r_{y^{\prime}}{ }^{2}}+\frac{d_{n i z}{ }^{2}}{r_{z}{ }^{2}}\right)\right)\right) \\
\left(i=1 \sim N_{x^{\prime}}, j \in c_{i}\right)
\end{array}
$$


$d_{n i \dot{x}}, d_{n i y}, d_{n i z}: n$ 番目の蟻が $i$ 番目に選択したメッシ 二の交点 $j$ から, $x, y, z$ 方向の各距離

$r_{x}, r_{y}, r_{z}$ : フェロモン情報を範囲付着する範囲を決定

寸る， $x^{\prime} ， y^{\prime}, z$ 方向にそれぞれ対応した係数 である.

式(8)の概念図を図一7 に示寸．図は $N_{d}=1$ として，あ る $i$ 番目の平面のメッシュにフェロモン情報を付与する 場合の例である. 蟻が通過した経路を矢印で示し，ある 蟻 $\mathrm{A}$ が $i$ 番目に選択したメッシュの交点を $P_{\mathrm{A}}$ ，る蟻 $\mathrm{B}$ が $i$ 番目に選択したメッシュの交点を $P_{\mathrm{B}}$ とする. また, フェロモン情報は高いほど赤くなるように表記する，す ると，図のように選択した $P_{\mathrm{A}}, P_{\mathrm{B}}$ を中心として，楕円 形にフェロモン情報が高くなるようにメッシュ内に付与 されている. なお, $N_{d}>1$ であれば球状にフェロモン情報 が付与されることになる.

$\mathrm{ACO}$ は,これまで探索してきた解に対してフェロモン 情報を付着し，そのフェロモン情報を基にさらに良質な 解の探索を行う。従って, 探索初期の段階で比較的良質 な解が得られた場合, その解周辺のフェロモン情報が高 くなり，局所解に陥る可能性も高くなる．このとき，探 索初期の段階では, 式(8)のフェロモン情報の付着範囲を 決定する係数 $r_{x}, r_{y}, r_{z}$ を比較的高い値に設定すれば, 少ない蟻の数でも設計空間全域に対してフェロモン情報 を付与させることが可能となり，局所解に陥ることを回 避できる. さらに, 探索後半では $r_{x}, r_{y}, r_{z}$ を比較的低 くすれば，良質な解周辺の空間には高いフェロモン情報 が付与されるため，良質な解周辺に対しても局所的に効 率良く経路の探索をすることが期待できる.

式(8)の各蟻が付着させるフェロモン情報を用いて,あ る時間 $t$ における設計空間全域のフェロモン情報は, $t+1$ において次式により変化させる.

$$
\begin{aligned}
\tau_{i j}(t+1)= & (1-\rho) \cdot \tau_{i j}(t)+\Delta \tau_{i j} \\
& \left(i=1 \sim N_{x^{\prime}}, j \in c_{i}\right)
\end{aligned}
$$

式(9)は, 各メッシュに付与されたフェロモン情報を $\rho$ の割合で蒸発させ, 新たに各蟻が通過した経路周辺のメ ッシュに対して, 新たにフェロモン情報を付与させるこ とを示している.

以上に示したアルゴリズムで, 3 次元空間内に最適な 経路を, ACO の概念の基に探索することが可能となった. 次章ではこのアルゴリズムを, 道路線形最適化問題へ応 用を試みた事例について説明する。

\section{4. 道路線形最適化問題一の応用}

上述した最適経路探索アルゴリズムを，道路線形最適 化問題へ応用した例について示す．提案する最適経路探 索アルゴリズムは, 3 次元空間内に対して直線の組み合 わせで経路が探索される. しかし，道路線形では直線と 曲線を組み合わせて路線が計画される.そこでここでは,

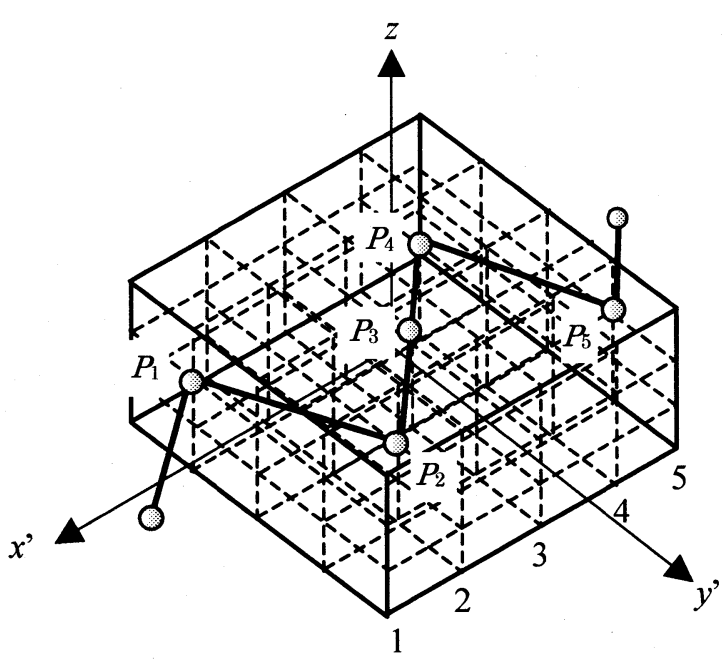

図ー8＼cjkstart直線の組み合わせによる経路

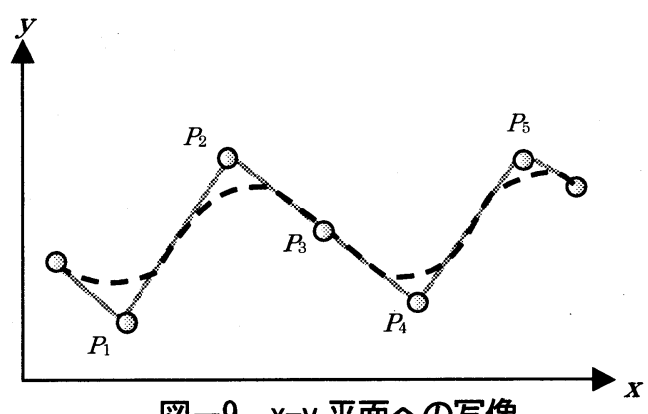

図-9 $\mathrm{x}-\mathrm{y}$ 平面への写像

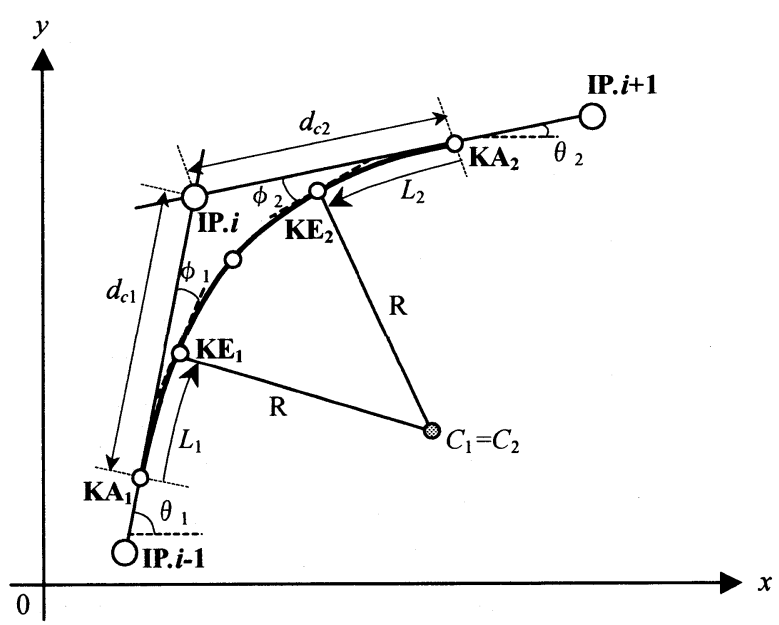

図-10 平面曲線の配置

直線の組み合わせで作成された経路に対して，曲線を含 む平面線形および維断線形を導入する方法について説明 する.

\section{1 平面線形の導入}

最適経路探索アルゴリズムで作成される経路は, 図一8 に示寸ように 3 次元空間内に対して全て直線の組み合わ せで構成されるため, 道路線形に直接応用することがで きない，そこで，この直線の組み合わせにより構成され る経路から，曲線を有する平面線形を得るために，まず 
$N_{x}$ 個選定された各折れ点 $P_{i}\left(i=1 \sim N_{x}\right)$ の $x$ 座標と $y$ 座標を 抽出し, 図一9 のように平面図に写像する. このとき, 各折れ点の交角が $0^{\circ}$ でなければ，そこに曲線を導入す ることになる. 寸なわち, 図一 9 では $P_{1}, P_{2}, P_{4}, P_{5}$ で 曲線を導入することになる.

ある $i$ 番目の箇所で曲線を導入する場合, 最適経路探 索アルゴリズムで選択された， $P_{i-1}, P_{i}, P_{i+1}$ 番目の 3 点 の情報を用いる. なお, 導入する曲線は, クロソイドと 円弧の組み合わせから構成されるものとする.

円弧の曲線半径 $R$ は, 道路構造令 ${ }^{5}$ に示される最小曲 線半径の望ましい值を使用した. またクロソイドに関し ては, 道路構造令に示される許容量最小パラメータ $A$ と

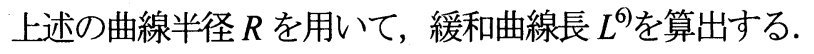
なお，曲線半径，およひ緩和曲線長は走行性などの観点 から, より長い方が望ましいとされる. そのため, いく つかの曲線半径の候補值から, 対象とする曲線部に応じ た曲線半径を各蟻に決定させる論理を組み込むことも可 能であるが, これらは今後の課題とし，ここでは一定の 曲線半径と緩和曲線長を用いた。

円弧，およびクロソイドの各パラメータが決定される と, クロソイドの起点, 終点, および円弧の起点, 終点 は以下のように決定される.

図一10のように，ある $i$ 番目の箇所で曲線を導入する 点（以下, IP. $i$ とする）から, IP. $i-1$ を結ぶ值線上に配置 されるクロソイドの起点を $\mathrm{KA}_{1}$ とする. また, IP. $i-1$ か ら IP. $i$ を結ぶ直線の傾きを $\theta_{1}, \quad$ IP.$i$ と KA の直線距離を $d_{c 1}$ とする.

クロソイドの各パラメータは上述のように決定されて おり, $\mathrm{KA}_{1}$ から緩和曲線長 $L_{1}$ 進んだ点 (円弧の起点) を,

$\mathrm{KE}_{1}$ と表す. IP. $i$-1 と IP. $i$ を結んだ直線と, $\mathrm{KE}_{1}$ との接線 角を $\phi_{1}$ とすると, $\phi_{1}+90^{\circ}$ の方向に曲線半径 $R$ 進んだ 位置が, IP. $i-1$ 方向から考えた場合の円弧の中心位置 $C_{1}$ となる.

同様に, IP. $i$ から IP $. i+1$ を結ぶ值線の傾きを $\theta_{2}$ とし, クロソイド終点を $\mathrm{KE}_{2}$ とする. そして, IP. $i$ と $\mathrm{KE}_{2}$ の直 線距離を $d_{c 2}$ とする. さらに, IP. $i$ と IP $i+1$ を結んだ直線 と, $\mathrm{KE}_{2}$ との接線角を $\phi_{2}$ とすると, $\mathrm{KE}_{2}$ から $\phi_{2}+90^{\circ}$ の 方向に曲線半径 $R$ 進んだ位置が, IP. $i+1$ 方向から考えた 場合の円弧の中心位置 $C_{2}$ となる. IP. $i-1$ 方向から考えた 場合の円弧中心位置 $C_{1}$ と, IP $i+1$ 方向から考えた場合の 円弧の中心位置 $C_{2}$ が一致するような $d_{c 1}$ と $d_{c 2}$ を決定すれ ば，クロソイドを含む円曲線が導入される.

$d_{c 1}$ および $d_{c 2}$ は, $C_{1}$ および $C_{2}$ の $x y$ 座標に関して連立 方程式を作成することにより, 結果的に次式により算定 される.

$$
d_{c 1}=\left(\begin{array}{l}
\tan \theta_{2} \times\left(\begin{array}{l}
C x_{1} \cos \theta_{1}+C y_{1} \sin \theta_{1}+R\left(\cos \theta_{d 1}-\cos \theta_{d 2}\right) \\
+C x_{2} \cos \theta_{2}-C y_{2} \sin \theta_{2}
\end{array}\right) \\
-C x_{1} \cos \theta_{1}+C y_{1} \sin \theta_{1}+R\left(\cos \theta_{d 1}-\cos \theta_{d 2}\right) \\
-C x_{2} \cos \theta_{2}-C y_{2} \sin \theta_{2}
\end{array}\right)
$$

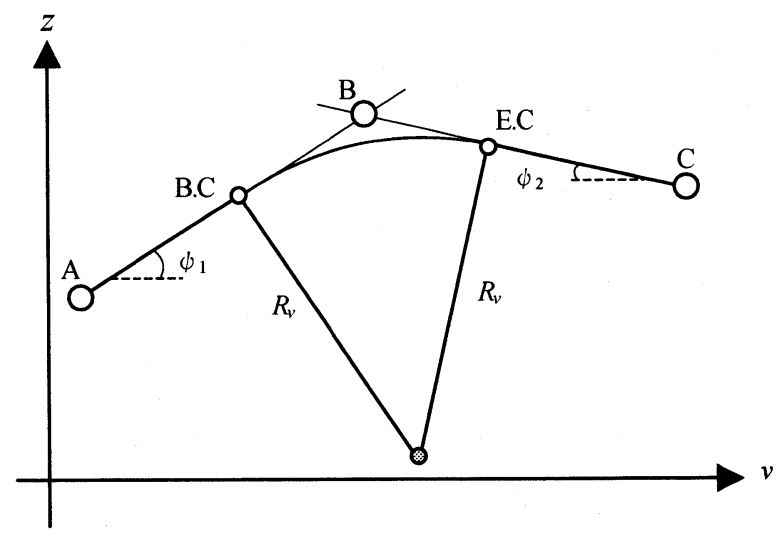

図-11 縱断曲線の配置

$$
\begin{aligned}
& d_{c 2}=\left(\begin{array}{l}
\left(C x_{1}-d_{c 1}\right) \times \cos \theta_{1}+C y_{1} \sin \theta_{1}+R\left(\cos \theta_{d 1}-\cos \theta_{d 2}\right) \\
+C x_{2} \cos \theta_{2}-C y_{2} \sin \theta_{2}
\end{array}\right) \\
& \quad / \cos \theta_{2} \\
& \text { ただし, } \theta_{2} \neq 0, \pm \frac{\pi}{2}
\end{aligned}
$$

ここで,

$C_{x 1}, C_{x 2}$ : クロソイド曲線長 $L_{1}, L_{2}$ および曲線半径 $R$ に 対応する, 主接線と直角方向への変動量 $(\mathrm{m})$

$C_{y 1}, C_{y 2}$ : クロソイド曲線長 $L_{1}, L_{2}$ および曲線半径 $R$ に 対応する, 主接線方向への変動量 $(\mathrm{m})$

$$
\begin{aligned}
& \theta_{d 1}=\pi / 2-\phi_{1} \\
& \theta_{d 2}=\pi / 2-\phi_{2} \\
& \phi_{1,} \phi_{2}: \mathrm{KE}_{1}, \mathrm{KE}_{2} \text { における接線角 }(\mathrm{rad})
\end{aligned}
$$

である.

なお，上述のように，メッシュ化した設計空間を用い て道路線形最適化問題に応用寸る場合, メッシュの分割 数によって道路の線形要素が決まることになる.メッシ ユの分割数を多くすれば，詳細に線形を検討できるが設 計空間は広くなり，良質な解の探索には比較的多くの時 間を要することになる. 一方，メッシュの分割数を少な くすれば，解の探索時間は減少できるが，良質な線形の 検討は行えなくなり, 設計者の判断による啇切なメッシ ユの分割数の設定が必要となる.

\section{2 維断線形の導入}

縦断線形は, 最適経路探索アルゴリズムによる $i-1$ 番 目と $i$ 番目, および $i+1$ 番目の折れ点の $z$ 座標と, 上述の 平面線形により算定される道路延長との関係より算定さ れる.

今, 図一11 のように, 横軸に道路延長 $v$, 縦軸に $z$ と し, $i-1, i, i+1$ 番目に選択された折れ点をそれぞれ $\mathrm{A}$, $\mathrm{B}, \mathrm{C}$ とする. さらに点 $\mathrm{A}$ から $\mathrm{B}$ への角度を $\phi_{1}$, 点 $\mathrm{B}$ から Cへの角度を $\phi_{2}$ と寸る. また, 縦断曲線半径を $R_{v}$ とする.

緹断曲線には緩和曲線を用いないため, 維断曲線半径 が決まれば, 縦断曲線の起点 B.C と終点E.C は, 前述の 
式(10)および式(11)に含まれる $\phi_{1}, \phi_{2}$ および $L_{1}, L_{2}$ の 值を 0 として, 座標系を $v$ と $z$ に変更すれば求めること ができる. なお, 縱断曲線の曲線半径は, 本研究では道 路構造令に示される縦断曲線半径の望ましい值の 2 倍を 用いる.

上述の平面線形，および維断線形の導入により計画路 線が決定されると, その路線周辺の地形は, 国土地理院 発行のデジタル数值地図とリンクし自動で認識される. この地形データを基に, 対象とする設計問題の目的関数 などを決定することになる.

以上に示した論理を基に, 次章では道路線形最適化問 題の数值計算例を示寸.

\section{5. 道路線形最適化問題の数值計算例}

ここでは，上述の最適経路探索アルゴリズムを，道路 線形最適化問題へ応用した数值計算例を示す. 以下に最 適設計問題の定式化，および数值計算結果を示す.

\section{1 対象地域}

路線計画の対象とするのは, 図一12 に示す札幌市周辺 の山地部とした. 路線計画の起終点の座標を $(x, y, z)$ と表す と, 起点の座標を $(1014,1684,134)$, 終点の座標を $(5783,5084,81)$ とした. 各座標の単位はいずれもメート ル $(\mathrm{m})$ である，なお，作成した最適経路算定アルゴリ ズムにおける座標系 $x$ および $y$ は, 緯度経度, および道 路線形に一般的に用いられる直交座標系それぞれに対応 している. しかし，ここに示した座標系は簡単化のため に, 図-12 に示寸設計の対象とする地形の範囲内で任意 に原点を作成した場合の座標系である.

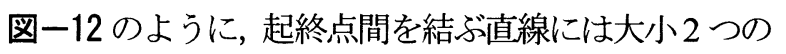
山が存在するように設定している. なお, 最適経路算定 アルゴリズムにおける起終点は, 従来線との連結などの ために接線角度を任意に設定できるが，本計算例では接 線角度の設定は行っていない.

\section{2 目的関数}

目的関数は直接工事費の最小化問題とした. 以下に目 的関数を示す.

$$
O B J=C_{r}+C_{p}+C_{b}+C_{t} \rightarrow \min
$$

ここで,

$C_{r}:$ 道路に関する直接工事費(unit)

$C_{p}:$ 舗装に関する直接工事費(unit)

$C_{b}:$ 橋梁建設に関する直接工事費(unit)

$C_{t}$ : トンネル建設に関する直接工事費(unit)

である.

検討する路線の道路区分は第 3 種第 3 級, 設計速度を $60 \mathrm{~km} / \mathrm{h}$ と仮定して計算を試みる. また幅員構成は, 車線 $3.0 \mathrm{~m}$, 路肩 $0.5 \mathrm{~m}$ で往復 2 車線と仮定した. 道路に関す

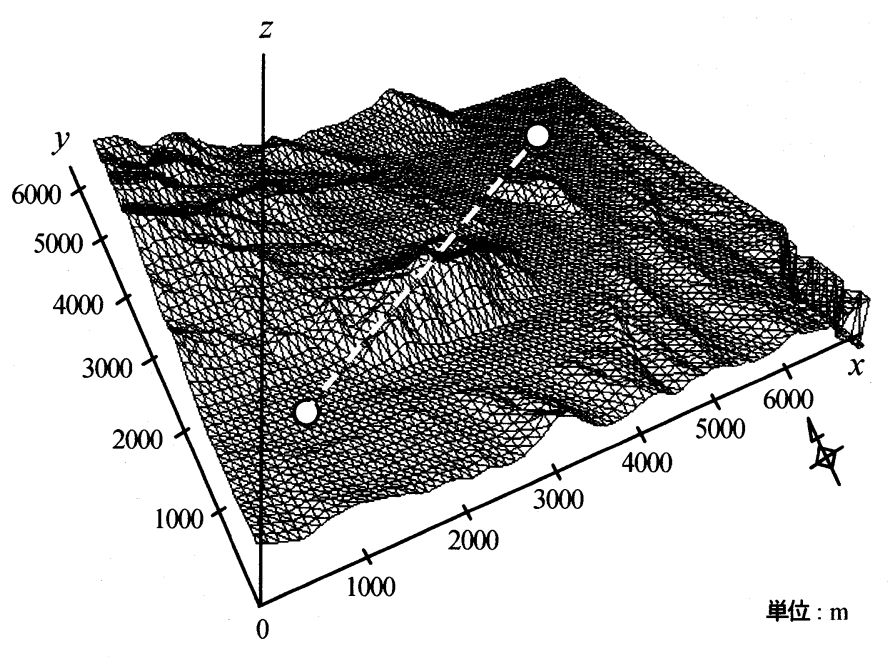

図-12 設計対象の地形図

表一1 道路に関する費用の単価

\begin{tabular}{|c|c|c|c|}
\hline \multicolumn{2}{|r|}{ 項目 } & 単位 & 単価 (unit) \\
\hline \multicolumn{2}{|r|}{ 伐開工 } & $\mathrm{m}^{2}$ & 1500 \\
\hline \multirow{3}{*}{ 土エ } & 掘削工 & $\mathrm{m}^{3}$ & 2000 \\
\hline & 路体盛土工 & $\mathrm{m}^{3}$ & 1500 \\
\hline & 路床盛土工 & $\mathrm{m}^{3}$ & 2000 \\
\hline \multicolumn{2}{|r|}{ 捨土 } & $\mathrm{m}^{3}$ & 3000 \\
\hline \multicolumn{2}{|r|}{ 客土 } & $\mathrm{m}^{3}$ & 2500 \\
\hline \multirow{2}{*}{ 法面工 } & 切土法面整形 & $\mathrm{m}^{2}$ & 1000 \\
\hline & 盛土法面整形 & $\mathrm{m}^{2}$ & 500 \\
\hline \multicolumn{2}{|r|}{ 法覆工 } & $\mathrm{m}^{2}$ & 1000 \\
\hline \multirow{3}{*}{ 排水工 } & U型側溝 & m & 6500 \\
\hline & 小段排水 & $m$ & 5000 \\
\hline & 路床排水 & $\mathrm{m}$ & 1500 \\
\hline 防護柵工 & ガードヶーブル & $\mathrm{m}$ & 8000 \\
\hline
\end{tabular}

表一2 舗装に関する費用の単価

\begin{tabular}{|c|c|c|c|}
\hline & 項目 & 単位 & unit \\
\hline \multirow{2}{*}{ 路盤工 } & 凍上抑制層 $(\mathrm{t}=60 \mathrm{~cm})$ & \multirow{5}{*}{$\mathrm{m}^{2}$} & 2,000 \\
\hline & 下層路盤 $(\mathrm{t}=25 \mathrm{~cm})$ & & 1,500 \\
\hline \multirow{3}{*}{ 舗装工 } & ア ス安定処理 $(=6 \mathrm{~cm})$ & & 1,000 \\
\hline & 粗粒度アスコン $(\mathrm{t}=5 \mathrm{~cm})$ & & 2,000 \\
\hline & 排水性舗装混合物 $(\mathrm{t}=\mathbf{4} \mathrm{cm})$ & & 1,500 \\
\hline
\end{tabular}

表－3 橋梁に関する費用の単価

\begin{tabular}{|c|c|c|}
\hline 支間長 $L_{B}(\mathrm{~m})$ & 単位 & 单価 (unit $\left.\times 10^{3}\right)$ \\
\hline $0<L_{B} \leq 20$ & \multirow{4}{*}{$\mathrm{m}^{2}$} & 100 \\
\hline $20<L_{B} \leqq 40$ & & 200 \\
\hline $40<L_{B} \leq 60$ & & 300 \\
\hline$L_{B} \geqq 60$ & & 350 \\
\hline
\end{tabular}

る直接工事費には，伐開工，土工，法面工，法覆工，排 水工，防護柵工，捨土，客土に関する費用を考慮した. 表-1 には本研究でモデル化した道路に関する直接工事 
費の単価を示す。

土工や法面工は，道路延長に対して $20 \mathrm{~m}$ 間隔でそれぞ れ算定寸る.このほか, クロソイド起終点, 円弧起終点, 縦断曲線起終点でもそれぞれ算定する. 土工の算定に用 いる地表高は, 前述のように国土地理院発行のデジタル 数值地図を用いて，対象とする地点の横断を含む標高デ 一タから算定する. 使用したデジタル数值地図は, 数值 地図 25000 を用いた。

土工が切土の場合，切土高さが $5 \mathrm{~m}$ 以下であれば, 1 ： 1.2 の法面とし， $5 \mathrm{~m}$ 以上であれば， $1: 1.5$ の法面で， $5 \mathrm{~m}$ に 1 つ幅 $1.0 \mathrm{~m}$ の小段を設けることとした. また，切土 の段数を最大 5 段とし， 5 段以上となる場合には，切土 に変わりトンネルを建設することとした.

一方，土工が盛土の場合，盛土高さが $5 \mathrm{~m}$ 以下であれ ば，1：1.5 の法面とし， $5 \mathrm{~m}$ 以上であれば $1: 1.8$ の法面 として, 5 メートルに 1 つ幅 $1.5 \mathrm{~m}$ の小段を設置すること とした. また, 盛土の高さが 3 段以上となる場合には, 盛土に変わり橋梁を建設することとした.

舗装に関寸る直接工事費は路盤工，およひ舗装工をそ れぞれ考慮した. 表一2 にモデル化した舗装に関する工 事費の単価を示寸。

橋梁に関する直接工事費は, PC 橋を前提として, 単位 橋面積当りの工事費を支間長別に設定した，設定した橋 梁の単価を表－3 に示す. トンネルに関する直接工事費 は，200万 unit/m と仮定して計算を試みた.

なお，道路線形の設計問題では，本研究が対象とした 工事費最小化問題のほか，景観性などの種々の目的関数 を検討する必要性があり，これらは今後の課題とする.

\section{3 制約条件}

制約条件は，平面線形および綻断線形に関する条件を 考慮した. 平面線形に関する条件は,

1. 道路構造令に示される望ましい最小曲線半径の值を 用いて，式(10)，式(11)により円弧を配置できる.

2. 道路構造令に示される許容量最小パラメータを用い て,クロソイド曲線を配置できる.

3. 曲線長が, 道路構造令に示される最小曲線長以上で ある。

とした. 一方，縦断線形に関する条件は，

1. 縦断勾配が道路構造令の規定值以下である.

2. 道路構造令に示される緹断曲線半径の望ましい值の 2 倍，あるいは必要縦断曲線長の規定值を用いて， 縱断曲線が配置可能である.

3. 平面曲線と縦断曲線が組み合わされる場合に, クロ ソイド起終点位置よりも内側に縦断曲線の起終点位 置が配置されている.

とした.

各設計解は，上述の各制約条件を満足しなければ，式 (7)に示したように, ペナルティー関数によって高い目的 関数となるため, 結果的に細かいアップダウンなどの

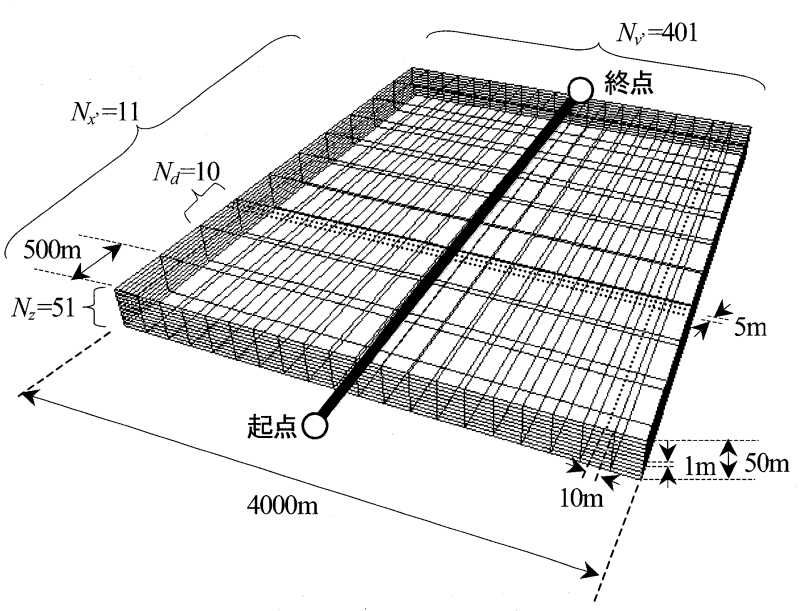

\section{図-13 設計空間}

極端な線形要素を有する設計解が最適解として選ばれる ことは少なくなる.さらに, 縦断線形の最小交点間隔の 目安などの制約条件を追加すれば，極端な線形を回避す ることが可能である.

一方, 道路の路線設計問題ではこのほか, 安全性や走 行性に関寸る条件なども考慮する必要性が考えられるが, これらを考慮するのは今後の課題として，ここでは上述 のような平面および縦断線形に関する条件のみを考慮す ることとした.

\section{4 設計変数}

設定した設計空間を図ー13 に示す. 図中の○で示した 線は，前述した起終点である.

設計変数は，まず $x$ ’方向の分割幅を $500 \mathrm{~m}$ とし，起終 点閒を 11 のメッシュで分割した $\left(N_{x}=11\right)$. さらに, $x$, 方向の各メッシュを 10 分割 $\left(N_{d}=10\right)$ し， $5 \mathrm{~m}$ 間隔で曲 線配置位置を調整できるものとした。

$y^{\prime}$ 方向に対しては，起終点を結ぶ直線を中心に $4000 \mathrm{~m}$ の範囲を設計の対象とした. この範囲に対して $10 \mathrm{~m}$ 間隔 でメッシュを作成することにより, $N_{y}=401$ として計算を 行った.

$z$ 方向に対しては起終点を結ぶ直線を中心に $50 \mathrm{~m}$ の 範囲内を設計の対象とした。この範囲に対して $1 \mathrm{~m}$ 間隔 でメッシュを作成することにより， $N_{z}=51$ として計算を 行った. なお，図一13 では描画が複雑となるため， $y^{\prime} お$ よび $z$ 方向の全てのメッシュは表記していない.

\section{5 数值計算結果}

道路線形最適化問題の数值計算結果を示す．まず，数 值計算に用いた $\mathrm{ACO}$ のパラメータを以下に示す.

1) 蟻の数 $n: 500$

2) フェロモン乗数 $\alpha: 3.0$

3) ヒューリスティック乗数 $\beta: 1.0$

4) ヒューリスティック付加情報 $\gamma_{i j}: h_{i j} z_{i j}$ 


\section{表ー4 ランダムシーズ別の最適解}

\begin{tabular}{|c|c|c|c|}
\hline $\begin{array}{l}\text { ランダム } \\
\text { シーズ }\end{array}$ & $\begin{array}{l}\text { 目的関数値 } \\
\left(\text { unit } \times 10^{6}\right)\end{array}$ & $\begin{array}{c}\text { 繰り返し回数 } \\
\text { (回) }\end{array}$ & 目的関数比 \\
\hline 1 & 2016 & 2211 & 0.08 \\
\hline 2 & 1914 & 1922 & 0.03 \\
\hline 3 & 1860 & 2613 & 0.00 \\
\hline 4 & 1980 & 2989 & 0.06 \\
\hline 5 & 1931 & 1608 & 0.04 \\
\hline
\end{tabular}

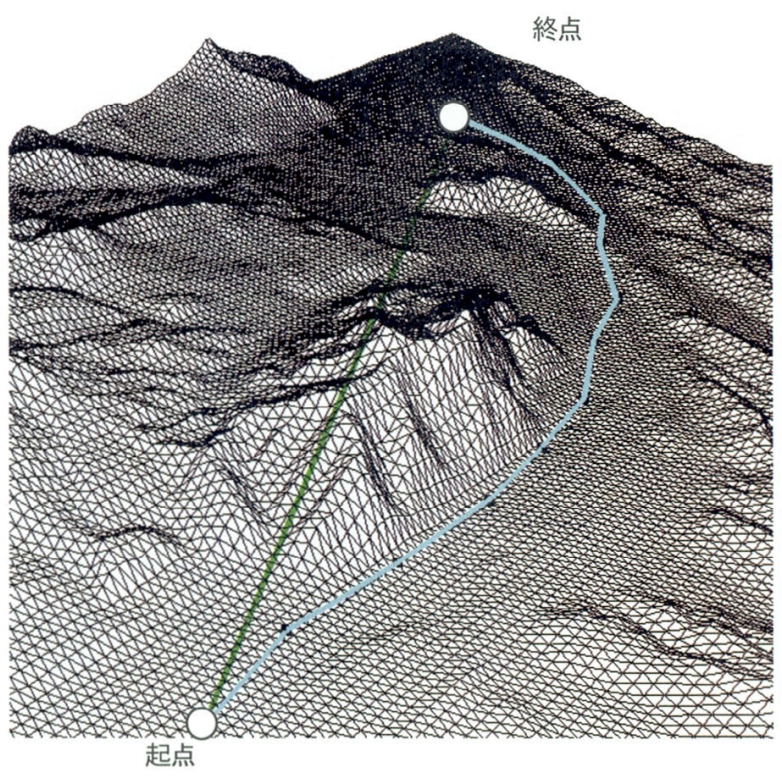

図ー15 最適経路探索アルゴリズムによる最適解

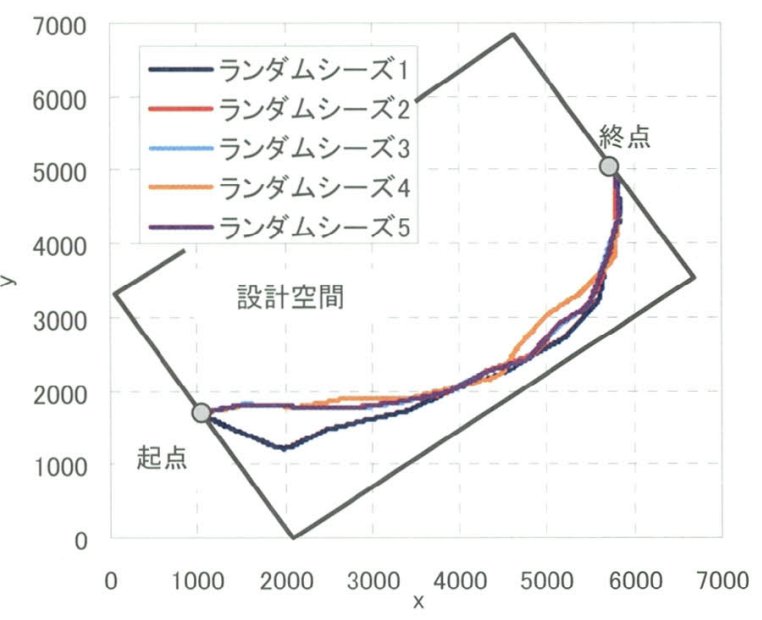

図一14 ランダムシーズ別の最適解の平面線形

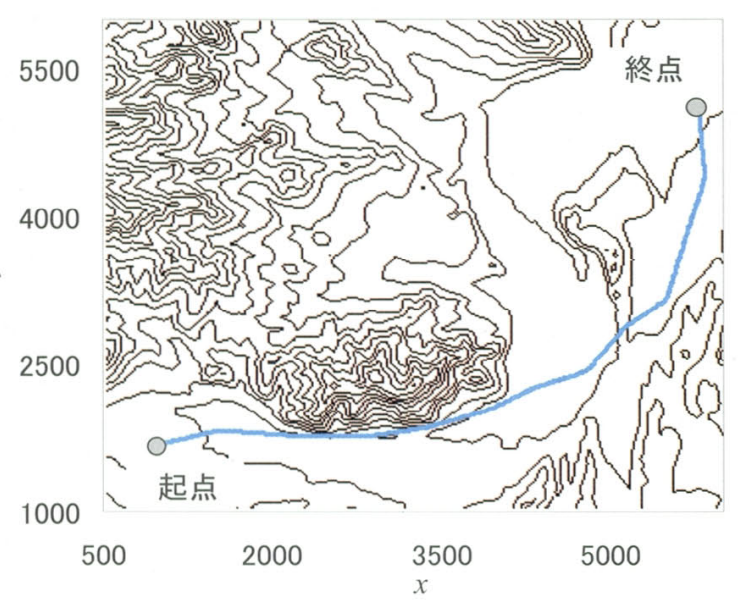

図一16 最適解の平面線形

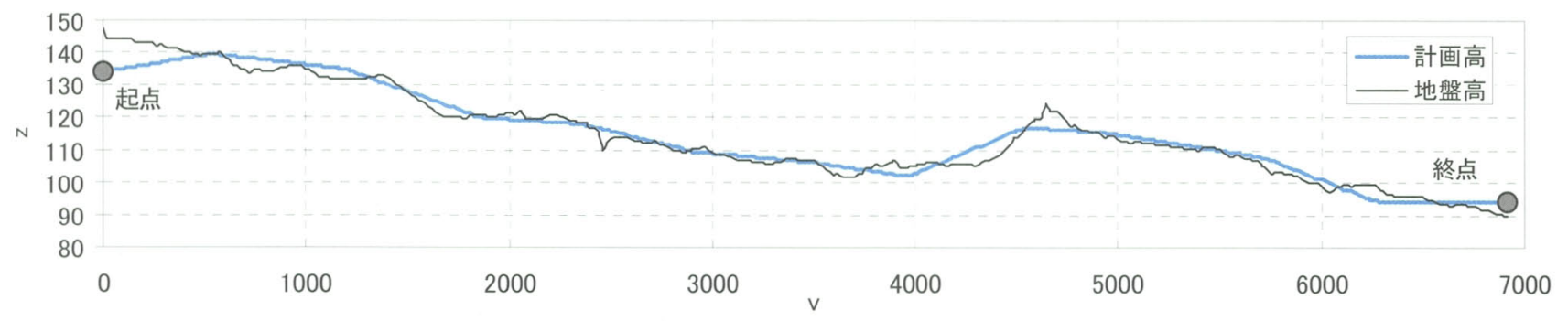

図一17 最適解の縱断線形

ここで,

$h_{i j}$ : メッシュ $i j$ に対応する地形の標高

$z_{i j}$ : メッシュ $i j の z$ 座標

である。

5) 最大繰り返し回数 $N_{\text {max }}: 5000$

6) 範囲付着係数 $r_{x}, r_{y}, r_{z}: N_{d} / 5, N_{y} / 5, N_{z} / 5$

ACO では式(1)に示したように，擬似乱数を用いて確 率的に経路の探索を行うが，使用する乱数によって算定
される解が大きく異なるのであれば, 最適化手法として 有効ではない，そこでまず，擬似乱数の元となるランダ ムシーズを 5 種類用意し，上述のパラメータを用いてそ れぞれ計算を行い，得られた設計解の比較から提案する 手法の安定性を確認する. 表一4にはランダムシーズ別 の最適設計解の目的関数值, 繰り返し回数, および目的 関数比をそれぞれ示した. 表中に黄色で示した箇所は, 5 つのランダムシーズのうち, 目的関数值が最小となった 
設計解である. また, 表中の繰り返し回数は, 最適解が 得られたときの繰り返し回数を表し，目的関数比は表中 の黄色で示した最小の目的関数值との差を割合で表した ものである.

5 つのランダムシーズのうち目的関数值が最小となっ たのは，ランダムシーズ 3 の設計解で $1860 \times 10^{6}$ unit，繰 り返し回数は 2613 回なった.

ランダムシーズ別に得られた最適解を比較すると, 最 小の目的関数值に比べ $3 \sim 8 \%$ の差となり, ランダムシー ズを変えても，極端に目的関数值が異なるような設計解 が得られていないことが確認できる，なお，最適経路探 索アルゴリズムを用いずに，ランダムに 100,000 回解を 探索すると, 目的関数值の平均は概小 15000 (unit $\times 10^{6}$ ) となった. 得られたランダムシーズ別の最適解は, ラン ダム探索による結果の $12 \%$ 程度となる解をいずれも探索 しており, 提案する最適経路探索アルゴリズムの探索能 力の安定性が確認できる.

次に, ランダムシーズ別に得られた最適設計解の平面 線形を, 図一14 に示寸. 図中の は起終点で, 黒の太線 で示した範囲内が設定した設計空間である.図のように, ランダムシーズ別に得られた各設計解は，いずれも極端 にルートが異なるような線形ではないことが確認できる。 また図中の青線は, 目的関数值が最大であるランダムシ ーズ1の線形であり,他の線形に比べ $x=2000 \mathrm{~m}, y=1000 \mathrm{~m}$ 付近で膨らんだ曲線であることがわかる.

5 つのランダムシーズの中で, 最小の目的関数となっ たランダムシーズ3の設計解の詳細を示寸. 図一15に最 適経路探索アルゴリズムにより得られた経路, 図一16に 平面線形, 図一17には維断線形を示寸. 図一16およひ図 -17 の は, いずれも図一15 の起終点と一致している. 図一17 は，青線が最適解の縦断線形，実線が地盤高であ る. また，図一18には切土量，および盛土量を示す．図 -18 より, 切土量は $84,726 \times \mathrm{m}^{3}$, 盛土量は $86,582 \times \mathrm{m}^{3}$ となった. 切土量と盛土量の比はわずか $2 \%$ 程度と, 土 量バランスが保たれた設計解であることがわかる.また, 得られた設計解にはコストの高い橋梁, およびトンネル が建設されることは無く, 切土と盛土のみの路線が探索 された.

\section{6. まとめ}

蟻の採餌行動をモデル化した ACO は，最短経路の探 索に特化した最適化手法である. しかし, 従来の $\mathrm{ACO}$ を用いて，最短経路を探索するような現実の問題は多く 存在しない. このような観点から, 本研究では蟻の採餌 行動が道を形成する行為であることに着目し，3 次元空 間内に対して最適な経路を作成するアルゴリズムを, 従 来の ACO を基に提案した. そして, 提案したアルゴリ ズムを道路線形最適化問題へ適用し, 数值計算例を示し た. 以下に, 本研究で得られた結果を示寸.

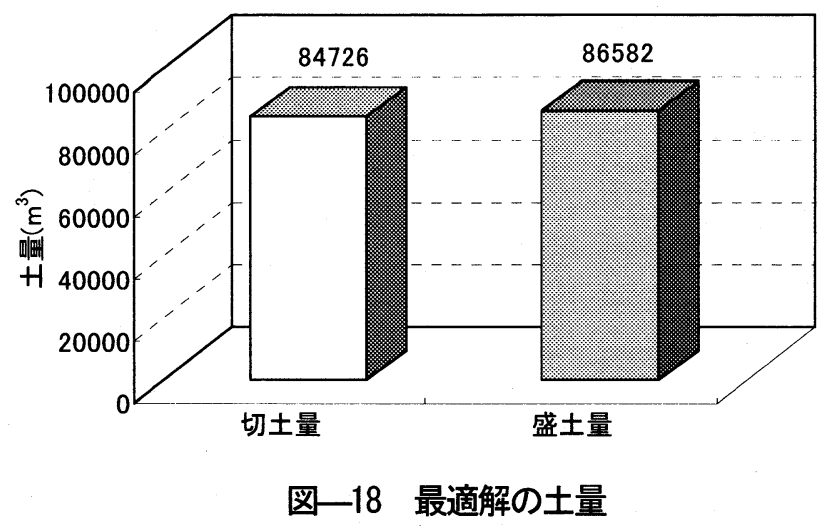

1） 3 次元空間内をメッシュで分割し, 経路およびフ エロモン情報を付着することによって，ACO を基 とした最適経路探索アルゴリズムを提案した.

2）最適経路探索アルゴリズムは，解の探索に距離 の概念を忘用することができるため, 路線計画の ような最適化問題に対して, 解の探索を合理的に 行うことが期待できる.

3）提案したアルゴリズムは，道路や鉄道の路線計 画や，河道計画などの現実的な種々の設計問題に 応用が可能である.

4）提案したアルゴリズムを，道路設計問題へ応用 した結果，異なるランダムシーズを用いても同程 度の質の解を探索することが可能となり，比較的 安定した手法であることが確認された.

5）最適解の詳細を検討すると，工費の最小化のみ ならず, 土工量のバランスが保たれた線形が得ら れており, 対象とする設計問題に適した最適な経 路を探索することができた.

一方，本研究は提案するアルゴリズムに対する基礎的 な研究であり, 今後の課題もいくつか考えられた. 以下 に, 今後の課題について示寸.

1）道路線形最適化問題への応用は, 道路構造令に示 される比較的簡単な制約条件のみを扱った.より現 実的な設計問題とするには,さらに詳細な制約条件 の設定が必要となる.

2）メッシュの分割数によって道路の線形要素数が 決定されるため, 適切なメッシュ分割数の設定が求 められる.

3）目的関数には直接工事費のみを扱ったが, 実際の 問題では景観性などの種々の目的関数があり,これ らを考慮した最適化が必要である.

4）地形データには既存の構造物や河川などの情報 を含めていないため,これらのデータを自動で認識 し, 回避するなどのアルゴリズムを追加する必要性 が考えられる. 
5）他の最適化手法との比較検討を行い, 本手法の有効 性の検討を行う必要性がある.

今後, これらの課題を検討し，アルゴリズムをさらに 改良することで，より現実的な設計問題に対応可能な手 法を構築したいと考えている.さらに，道路線形の夕な らず，鉄道や河道計画などへの応用も試みたいと考えて いる.

\section{参考文献}

1) Marco Dorigo and Thomas Stutzle:Ant Colony Optimiz ation, Bradford Book, 2003.

2) 阿部淳一, 杉本博之 : Ant Colony Optimization の構造 最適設計への応用について, 北海学園大学 工学部研
究報告 第 35 号, pp.23-26, 2008.

3) 杉本博之, 鹿美麗, 山本洋敬 : 離散的構造最適設計の ための GA の信頼性向上に関する研究，土木学会論文 集, No.471/I-24, pp.67-76, 1993.

4) 山崎元也, 本郷廷悦, 比屋根一雄, 谷田部智之, 遺伝 的アルゴリズムによる高速道路線形最適化のための 線形モデルの検討，土木学会論文集，No.758/IV-63, pp.57-69, 2004.

5) 日本道路協会 : 道路構造令の解説と運用, 丸善株式会 社, 2006.

6) 日本道路協会 : クロソイドポケットブック, 丸善株式 会社, 2000.

(2008 年 4 月 14 日 受付) 